\title{
MANAGERIAL OPTIMISM AND DEBT FINANCING: CASE STUDY ON INDONESIA'S MANUFACTURING LISTED FIRMS
}

\author{
Gesti Memarista \\ Universitas Kristen Petra, Surabaya - Indonesia
}

\begin{abstract}
Managerial's psychology can affect financial decision in the company. This paper analyzes the influence of managerial optimism on the debt financing by using regression analysis. The dependent variable in this paper is debt financing. The independent variable is managerial optimism and the control variable are firm value, firm size, and firm performance that are occurred in the previous period. The samples used in this study are manufacturing companies that listed in Indonesian Stock Exchange during 2010-2014. The result on this study shows that managerial optimism, firm value, and firm size that are occurred in the previous period have positive significant effect on debt financing, whereas firm performance in the previous period has negative significant impact on debt financing.
\end{abstract}

Keywords: Managerial Optimism, Debt Financing, Firm Value, Firm Size, Firm Performance

JEL Classification: G02, G30, G32

\section{INTRODUCTION}

Corporate managers can take important decisions. If the decision made is correct, then it will benefit the company. Conversely, if the decision is wrong, it will make the company suffered losses. One form of important decisions that must be taken appropriately by manager is about capital structure (DeAngelo, et al., 2008).

Capital structure defines as financing decision in the company. Manager's decision aims to generate optimal capital structure by using debt
(Brigham \& Daves, 2009). Debt is funding from the external company. It can be a bond issuance and loan from banks. Debt financing will reduce tax, but the risk of bankruptcy will increase, if firms use debt too much.

According to Myers (1976), managers have a rational decision such as they do not want to have high debt financing. It is because managers want to protect their position and their wealth. Therefore, manager will limit debt financing to concern about investor's expectation for the company in the future. Higher debt will give a bad signal to the in-

Korespondensi dengan Penulis:

Gesti Memarista. HP: +6285730110709

e-mail: gesti@petra.ac.id 
vestor, that company has riskier condition next year later.

Not only a rational manager try to get maximum utility in company's decision, but also an irrational managers (Park \& Kim, 2009). Usually, an irrational manager only uses cognitive psychological to make a decision. Cognitive psychological will show someone's mental processes (American Psychological Association, 2016). It contains individual's memory, perception, and problem solving before someone make decisions. For example, manager's experience in leading corporate may cause a perception that will influence their decision. When manager only use experience with the historical memory as the basic of decision making, it can lead a mistake for random and unpredictable result.

The previous studies stated that an irrational behavior of managers such as over optimism will happen when they make a decision (Ackert \& Daves, 2010). According to Heaton (2002), the irrational behaviour causes the manager to underestimate the risk and to overestimate the result of decision. Roll (1986) stated that there is hubris hypothesis. The hypothesis shows that managers are too optimistic because of the misleading perception about the future benefit. Hereafter, optimistic manager will issue more bond and loans than equity, because manager believe that the firm will be able to pay the principal and the interest (Park \& Kim, 2009).

Managers will be more optimistic when they have control over the company through managerial ownership (March \& Sharpia, 1987). With this optimism, manager will have more debt in the next period when there is a good firm performance. As the firm grows, managers who seek external funding for investment will tend to overestimate the value of the project (Malmendier \& Tate, 2008). Based on Heaton (2002), financing decision of overconfident managers are more in the interests of shareholders than the rational manager's decisions. Furthermore, higher firm value will lead higher debt.

In Indonesia, the majority managers of go public firms in manufacturing sector, stated optimistic for good future performance in the annual report. This statement will affect the internal decision and the investors who read the annual report. As the manufacturing firms have a lot of necessities, so the firm will need more external fundings such as debt funding.

This paper aims to investigate the impact of irrational managerial on the company's decision. In this study, the researcher will analyse the affect of managerial optimism, firm value, firm size, and firm performance, that are occurred in the previous period to debt financing. The sample in this paper is manufacturing firms that listed in Indonesia Stock Exchange during 2010-2014.

\section{Debt Funding}

Every firm needs funding to support their sales by combining the debt and the equity (Brigham \& Daves, 2009). The combining sources of funding is called capital structure. Furthermore, in different industries, the company will have different capital structure. According to Miller (1977), when the companies want to get tax benefits from interest payments, the companies prefer to use debt financing. Converserly, companies will use equity financing, when there is the more profitable tax treatment of income from stock that can lower the required return on stock.

Generally, companies prefer to use debt rather than equity. The use of debt can provide several advantages, although there is still a financial risk. The presence of flotation cost may cause the company raises capital according to pecking order theory (Ross, et al., 2008). In this theory, the firm will use internal source first, and then external source. For the external source, firm will issue debt then equity. This is due to the issuance 


\section{Jurnal Keuangan dan Perbankan | KEUANGAN}

Vol. 20, No.3, September 2016: 438- 447

of equity is more expensive than debt issuance. Furthermore, according to Brigham \& Daves (2009), debt offering will give a positive signal that company has good prospect ahead. Firm with positive prospect will not try to sell more stocks. In addition, debt financing can solve agency conflict as the bonding mechanism and increase the value of the firm (Jensen \& Meckling, 1976 and Megginson, 1997).

\section{Managerial Optimism}

The manager of the company can make an excessive assessment about the firm performance. It will show the manager's overconfidence. According to Ackert \& Daves (2010), the manager's overconfidence happens because the manager feels like having good at the level of knowledge, the ability of management, the accuracy of information, or the controlling of information.

One form of overconfidence is managerial optimism (Glaser \& Weber,2007). Managerial optimism is involved with manager's position (March \& Shapira, 1987). In the good position, managers have power to control everything as they want. Manager can assign probabilities to favorable or unfavorable outcomes that are just too high or too low based the manager's experience (Ackert \& Daves, 2010). Optimistic managers will overestimate the return, such overestimate the firm performance.

Managerial optimism can effect financial decision of the company (Heaton, 2002 and Park \& Kim, 2009). Manager can overestimate the firm's profitability, then they will choose debt than equity (Hackbart, 2008). Manager feels optimistic about the future that company can face the financial risk for having debt financing, because the company has good performance. When managers are more optimistic, so the debt financing is more higher in the next year (Park \& Kim, 2009). Therefore, based on the literature, the first hypothesis is:
Hypothesis 1: Managerial optimism about the previous period has positive effect on debt financing

\section{Firm Value}

The company's goal is to maximize the value of the firm (Ross, et al., 2008). This goal will be achieved by increasing the shareholder's wealth of company. The higher firm value indicates the increasing of shareholder's interest to the company. This is due to the market perceptions about the increasing of company's growth. Market value will be determined by looking forward in time (Frank \& Goyal, 2003). Market value will indicate the firm position in the market. According to Park \& Kim (2009) market value will lead the company to get more the leverage than the retained earnings. So, based on the literature, the second hypothesis is: Hypothesis 2: Firm value in the previous period has positive effect on debt financing

\section{Firm Size}

Firm size can determine the firm's cash flow position. Larger firm size indicates that the company has good cash flow position (Moeljadi \& Supriyati, 2014). Firm size can be measured in a number of ways such as by sales, total assets, the number of workforce, and firm age (Brigham \& Daves, 2009). Based on Rajan \& Zingales (1995), firm size has positive significant effect the leverage. The larger firm size, will be less volatile. This is a signal that firm has good prospect, so firm will use more debt financing. Therefore, based on the literature, the third hypothesis is:

Hypothesis 3: Firm size in the previous period has positive effect on debt financing

\section{Firm Performance}

Firm performance indicates the historical achievement of the company. According to 
Valentin (2015), the measurement of firm's performance can be showed by classical indicator. The classical indicator will show the company's performance by the past by existing value, such as profitability ratio. Higher profitability means that the firm has good performance to make further financial decision. The firm with more profit has lower prediction of financial distress (Frank \& Goyal, 2003). With higher profitability, firm will use more debt in the next period. Therefore, based on the literature, the fourth hypothesis is:

Hypothesis 4: Firm performance in the previous period has positive effect on debt financing

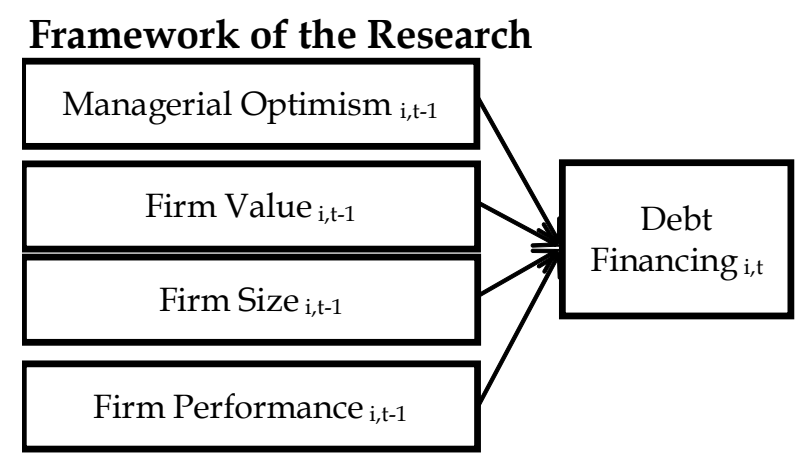

Figure 1. Framework of the Research

\section{METHODOLOGY}

This study used the multiple linear regression to analyse the effect of managerial optimism to debt financing. The regression will pass through the classical assumption test such as normality, autocorrelation, heteroscedasticity, and multicollinerity. Then, the function of the equation model is formulated as follows:

Debt $=f($ Managerial Optimism, Firm Value, Firm Size, Firm Performance)

And the estimation model is:

$$
\begin{aligned}
\text { DEBT }_{\mathrm{i}, \mathrm{t}}= & \beta_{\mathrm{o}}+\beta_{1} \text { MOPT }_{\mathrm{i}, \mathrm{t}-1}+\beta_{2} \text { FVALUE }_{\mathrm{i}, \mathrm{t}-1}+ \\
& \beta_{3} \text { FSIZE }_{\mathrm{i}, \mathrm{t}-1}+\beta_{4} \text { FPERFOM }_{\mathrm{i}, \mathrm{t}-1}+\varepsilon_{\mathrm{i}, \mathrm{t}}
\end{aligned}
$$

Where, DEBT is debt financing, MOPT is the managerial optimism, FVALUE is the firm value, FSIZE is the firm size, FPERFORM is firm performance, $\beta_{\mathrm{o}}$ is the intercept of regression, $\beta_{\mathrm{i}}$ is the coefficient of regression, and $\varepsilon$ is the error term.

The sample in this research used manufacturing firms listed in Indonesia Stock Exchange during 2010 until 2014. The sample selection using purposive sampling method that select objects based on the certain criteria prescribed by the researcher, such as the company has positive equity and positive sales. This is due to negative equity value as the denominator would be meaningless, because the company suffered capital deficiency. Furthermore, the company must has positive sales, because the firm size requires the transformation using the form natural logarithm (Ln).

\section{Dependent Variable}

Debt financing indicates the number of external funding sources to fund the companies that can be obtanied through the company's loans from the banks or by issuing bonds. The indicator for this variable is determined by debt ratio to measure the proportion of the funds coming from debt to finance the company's assets (Ross, et al., 2008). The formula for the debt ratio is as follows:

$\mathrm{DAR}_{\mathrm{it}}=\frac{\text { total debt it }}{\text { total assets it }}$

\section{Independent Variable}

Managerial optimism is difficult to measure (Heaton, 2002 and Hackbarth, 2008). This is due to there is no directly measurement of managerial optimism for quantifying proxy (Park \& Kim, 2009). So, the indicators variable for managerial optimism in this reserach will follow several previous studies, such as:

1. Manager may express his optimism for the future company's condition in the annual report as the message and the impression of 


\section{Jurnal Keuangan dan Perbankan | KEUANGAN}

Vol. 20, No.3, September 2016: 438- 447

manager (Malmendier \& Tate, 2005b). This is done by mentioning the words such confident, confidence, optimistic, optimism, and the number of articles containing the words reliable, cautious, conservative, pratical, frugal, or steady in the annual report. These statements shows the expression that can indicate managerial optimism as the subjectively opinion of the manager.

2. According to Weinstein (1980), manager will be optimistic when they believe that the output is under control. According to Malmendier \& Tate (2005), CEO who served at least 5 years is much more understand about the company's performance and more optimistic about the company's ability to assess and control all policies. CEO with longer tenure will have more experience, so they may be more optimistic (Frank, 1988 and Fraser \& Greene, 2006).

3. If $\mathrm{BOD}$ as the manager of the firm, still choose to increase their stocks, so they are more optimistic about the company's performance in the future (Malmendier \& Tate, 2005 and Ye \& Wuhan, 2008). Manager as the shareholder may increase the stock as stock dividend, bonus, or compensation that given by the company. Manager sometimes buy or sell shares in pursuit of profit by trading with inside information. So, the stock price will fluctuate after the insider trading.

The indicator of managerial optimism in the previous period for this study will use dummy variable, equal 1 if the tree indicators above are met, and equal 0 , if those condition are not met.

\section{Control Variables}

\section{Firm Value}

Based on Ross, et al. (2008), the firm value will be indicated by the ratio of market value to book value of equity. This indicator will show the assessment of market to the firm. The higher market value to book value ratio means that the managers have been managed very well to increase the investor's assessment about the company. The formula for the firm value in the previous period is as follows:

$$
\begin{aligned}
\mathrm{FV}_{\mathrm{it}-1}= & \frac{\text { market value of equity it }-1}{\text { book value of equity } t-1}= \\
& \frac{\text { (outstanding share it }-1) \times(\text { closing price it }-1)}{\text { total equity it }-1}
\end{aligned}
$$

\section{Firm Size}

Firm size will show how large a company (Moeljadi \& Supriyati, 2014). So, the cash flow position will be known. Firm size also indicates the flexibility and the ability to get the fund by knowing the growth of sales. The indicator for firm size in this study will use natural logarithm of size. Therefore, the formula for firm size in the previous period is as follow:

FSIZE $_{\mathrm{t}-1}=\ln$ Sales ${ }_{\mathrm{t}-1}$

\section{Firm Performance}

Firm performance will show the firm profitability. The indicator of firm performance in this reserach is indicated by ROA. This ratio shows the ability of the firm for using company's assets to generate net income after tax (Ross, et al., 2008). The greater the value of this ratio, the company will be more efficient in using assets, then the firm performance is getting better. The formula for the firm performance in the previous period is as follows:

$\mathrm{ROA}_{\mathrm{it}-1}=\frac{\text { net income it }-1}{\text { total assets } \text { it }-1}$

\section{RESULT}

Tabel 1 is the descriptive statistics of all variables in this research. This study uses 30 manufac- 
turing listed firms in Indonesia Stock Exchange from 2010 until 2014. Some variables are presented in ratio form, such as debt financing, firm value, firm size, and firm performance, but managerial optimism is presented as dummy variable (equal 1 , if the managers are optimistic and equal 0 , if the managers are not optimistic).

Tabel 2 is descriptives statistics for each sector in manufacturing firms that was used in this research. The manufacturing firms were grouped in 3 sector categories in Indonesia. There are basic and chemical industry, various industries, and consumer goods industry. From the table above, the majority manager in basic and chemical industry and various industries are optimistic. On the contrary, the majority manager in the consumer goods industry are not optimistic and also has the least debt on average.

Table 3 is the result from classical assumption tests of linear regression model. From the table above, the regression result has passed the classical assumption tests. Based on the significant value of normality test (One-Sample KolmogorovSmirnov Test) is already greater than 0,05 , so the normality assumption has been fulfilled. The VIF value is less than 10 and the Tolerance (Tol.) value is more than 0,1 , then there is no multicollinearity. Based on the Glejser test significant value of each independent variables on the absolute residuals are greater than 0,05 , then there is no heteroscedasticity. Furthermore, there is no autocorrelation, because Durbin Watson value lies in $-2<\mathrm{DW}<+2$.

Table 1. Descriptive Statistics of All Variables

\begin{tabular}{|c|c|c|c|c|c|c|}
\hline Descriptive Statistics & $\mathbf{N}$ & Min & Mean & Max & Median & Sd \\
\hline $\operatorname{DEBT}_{(i, t)}$ & 150 & 0,037 & 0,416 & 0,854 & 0,407 & 0,084 \\
\hline $\mathrm{MOPT}_{(\mathrm{i}, \mathrm{t}-1)}$ & 150 & 0,000 & 0,613 & 1,000 & 1,000 & 0,490 \\
\hline FVALUE $_{(\mathrm{i}, \mathrm{t}-1)}$ & 150 & 0,145 & 2,681 & 49,990 & 1,010 & 0,046 \\
\hline $\operatorname{FSIZE}_{(\mathrm{i}, \mathrm{t}-1)}$ & 150 & 24,969 & 28,159 & 31,989 & 28,252 & 6,361 \\
\hline FPERFORM $_{(\mathrm{i}, \mathrm{t}-1)}$ & 150 & $-0,092$ & 0,097 & 0,981 & 0,079 & 0,063 \\
\hline
\end{tabular}

Table 2. Descriptive Statistics For Each Sector in Manufacturing Firms

\begin{tabular}{lccc}
\hline \multicolumn{1}{c}{ Descriptive Statistics } & Basic and Chemical & Various Industries & Consumer Goods \\
\hline Mode & & & 0,000 \\
MOPT $_{(\mathrm{i}, \mathrm{t}-\mathrm{l})}$ & 1,000 & 1,000 & 0,365 \\
Mean $_{\text {DEBT }_{(\mathrm{i}, \mathrm{t})}}$ & 0,386 & 0,515 & 4,479 \\
FVALUE $_{(\mathrm{i}, \mathrm{t}-\mathrm{l})}$ & 1,508 & 1,456 & 28,656 \\
FSIZE $_{(\mathrm{i}, \mathrm{t}-\mathrm{l})}$ & 27,015 & 28,640 & 0,105 \\
FPERFORM $_{(\mathrm{i}, \mathrm{t}-1)}$ & 0,113 & 0,068 & \\
\hline
\end{tabular}

Table 3. The Classical Linear Regression Model (CLRM)

\begin{tabular}{|c|c|c|c|c|c|}
\hline \multirow{2}{*}{ Model Statistics } & \multirow{2}{*}{$\begin{array}{l}\text { One-Sample Kolmogorov- } \\
\text { Smirnov (Sig.) }\end{array}$} & \multicolumn{2}{|c|}{ Collinearity Statistics } & \multirow{2}{*}{$\begin{array}{l}\text { Glejser Test } \\
\text { (Sig. t) }\end{array}$} & \multirow{2}{*}{$\begin{array}{l}\text { Durbin } \\
\text { Watson }\end{array}$} \\
\hline & & Tol. & VIF & & \\
\hline $\operatorname{MOPT}_{(\mathrm{i}, \mathrm{t}-1)}$ & \multirow{4}{*}{0,401} & 0,908 & 1,101 & 0,053 & \multirow{4}{*}{0,797} \\
\hline FVALUE $_{(\mathrm{i}, \mathrm{t}-1)}$ & & 0,506 & 1,976 & 0,434 & \\
\hline $\operatorname{FSIZE}_{(\mathrm{i}, \mathrm{t}-1)}$ & & 0,837 & 1,195 & 0,589 & \\
\hline FPERFORM $_{(\mathrm{i}, \mathrm{t}-1)}$ & & 0,536 & 1,867 & 0,434 & \\
\hline
\end{tabular}




\section{Jurnal Keuangan dan Perbankan | KEUANGAN}

Vol. 20, No.3, September 2016: 438- 447

Table 4 shows the result of regression analysis in this study. From the Sig. $t$ value of the regression analysis results show that managerial optimism in the previous period significantly positive affect on debt financing at level $5 \%$. In addition, firm value and firm size, that are occurred in the previous period significantly positive affect on debt financing at level 1\%. Otherwise, firm performance in the previous period significantly negative affect on debt financing at level $1 \%$.

Refer to Table 4, the result shows that the Adj. R-Square is $34,9 \%$. It means managerial optimism, firm value, firm size, and firm performance, that are occurred in the previous period explain the variability of debt financing at the level of $34,9 \%$. Moreover, the value of Sig. F is significant at $1 \%$. Thus the result of regression model is robust enough and it has goodness of fit.

\section{DISCUSSION}

Table 5 shows the results of hypothesis in this research. This is the following explanation about the results. The outcome of the study shows that managerial optimism has significant positive affect on debt financing at 5\% significance level. This result is consistent with Heaton (2002) and Park \& Kim (2009). According to Myers (1976), a rational manager will limit borrowing, although interest rate is the tax deductible and debt is as the bonding mechanism. But, when manager is optimistic about the future, the manager will be more overconfidence. So manager will take a decision based on their point of view by increasing the debt financing. This is due to the manager's belief that the company will have good condition and will able to pay the debt (the principal and

Table 4. Regression Analysis Result

\begin{tabular}{lcccc}
\hline \multirow{2}{*}{ Model Statistics } & \multicolumn{2}{c}{ Regression Analysis } & ANOVA & Model Summary \\
\cline { 2 - 5 } & Unstand. Coeff. & Sig. $\mathbf{t}$ & Sig. $\mathbf{F}$ & Adj. R- Square \\
\hline Constant & $-0,621$ & 0,016 & $0,000^{* * *}$ & 0,349 \\
MOPT $_{(\mathrm{i}, \mathrm{t}-\mathrm{l})}$ & $0,067^{* *}$ & 0,015 & & \\
$\mathrm{FVALUE}_{(\mathrm{i}, \mathrm{t}-1)}$ & $0,017^{* * *}$ & 0,000 & & \\
FSIZE $_{(\mathrm{i}, \mathrm{t}-1)}$ & $0,038^{* * *}$ & 0,000 & & \\
FPERFORM $_{(\mathrm{i}, \mathrm{t}-1)}$ & $-1,416^{* * *}$ & 0,000 & & \\
\hline
\end{tabular}

Note: ${ }^{*}, * *$, and $* * *$ denote statistical significance at $10 \%, 5 \%, 1 \%$ levels, respectively.

Table 5. The Results of Hypothesis

\begin{tabular}{|c|c|c|c|}
\hline Hypothesis & Results & Significance Level & $\begin{array}{c}\text { Supported by Previous } \\
\text { Research }\end{array}$ \\
\hline $\begin{array}{l}\mathrm{H}_{1} \text { : Managerial optimism in the } \\
\text { previous period has positive affect } \\
\text { on debt financing }\end{array}$ & Accepted & $5 \%$ & $\begin{array}{l}\text { Heaton (2002) and Park \& Kim } \\
\text { (2009) }\end{array}$ \\
\hline $\begin{array}{l}\mathrm{H}_{2} \text { : Firm value in the previous } \\
\text { period has positive affect on debt } \\
\text { financing }\end{array}$ & Accepted & $1 \%$ & $\begin{array}{l}\text { Myers (1976) and Frank \& } \\
\text { Goyal (2003) }\end{array}$ \\
\hline $\begin{array}{l}\mathrm{H}_{3} \text { : Firm size in the previous period } \\
\text { has positive affect on debt } \\
\text { financing }\end{array}$ & Accepted & $1 \%$ & $\begin{array}{l}\text { Gertler \& Gilchrist (1994), Rajan } \\
\text { \& Zingales (1995), Kumar, et al. } \\
\text { (2001), and Moeljadi \& } \\
\text { Supriyanti (2014) }\end{array}$ \\
\hline $\begin{array}{l}\mathrm{H}_{4} \text { : Firm performance in the } \\
\text { previous period has positive affect } \\
\text { on debt financing }\end{array}$ & Rejected & $1 \%$ & $\begin{array}{l}\text { Frank \& Goyal (2003), Hackbart } \\
\text { (2008), Brigham \& Daves (2009), } \\
\text { and Valentin (2015) }\end{array}$ \\
\hline
\end{tabular}


the interest), so the more optimistic a manager, then the debt financing will increase.

Firm value has significantly positive affect on debt financing at $1 \%$ significance value. This result is same as the findings from Frank \& Goyal (2003), higher firm value means that shareholders have a great attention to the firm. Most firms are valued as going concerns, so market will assess the company. It reflects the shareholder's expectation about the continuing of future investment and the opportunity (Myers, 1976). Thus, this condition will make company creates further investment on possibility and have good challenge to finance the company by using debt. Higher firm value in the previous period cause higher debt at the next year.

In this study, firm size also has significantly positive affect on debt financing at $1 \%$ significance level. According to Rajan \& Zingales (1995), larger firm size indicates positive signal of business. As the aspect of economic growth in the business, the growth in the size of company is interesting topic (Kumar, et al., 2001). Firm size is important to economic phenomena such as when the size of the firm is small, the firm will tight the monetary policy (Gertler \& Gilchrist, 1994). So higher the firm size, the company will have higher debt financing.

Firm performance has negative significant on debt financing at $1 \%$ significance level. This result is consistent with (Frank \& Goyal, 2003). But, this result is not consistent with the previous hypothesis, that firm performance has positive significant on debt financing. According to Frank \& Goyal (2003), better firm performance indicates more profitability, so the company can face the future with internal financing (retained earnings). Based on this explanation, when the firm has higher firm performance, the debt financing will decrease (Brigham \& Daves, 2009). This is due to the ability of the internal fund can support the financing in the firm. Furthermore, with lower debt, financial risk will decrease, so there is no financial distress and bankruptcy.

\section{CONCLUSION}

Based on some previous studies, managerial optimism as the financial behaviour topic is the latest topic and very interesting topic for research. It is intended to find out the background of a manager to make a decision. In this study, the result of regression analysis shows that managerial optimism, firm value, and firm size, that are occurred in the previous period have positive significantly impact on debt financing, whereas the firm performance in the previous period has negative significantly impact on debt financing. The optimistic manager today can affect the financing decision to get debt for next period. The more optimistic manager, the more debt will take on the future.

In addition, by knowing these benefits, it is not only contributes to the related literature, but also has practical implication in corporate finance policies. For internal stakeholders in the company, they will be more motivated because they do believe with this condition forecasting. They also can have higher projection for sales growth. For external party, this is such a positive signal for investor. The investors can assess that manager who optimistically believe that the performance of the company in a better future and able to pay the debt (the interest and the principal). Investor who will buy the company's stock will be convinced, because the manager believes with the condition of the company in the future.

\section{LIMITATION}

Furthermore, the managerial optimistic measurement in this research is an improvement. The measurement of managerial optimistic done by combining the managerial statement in annual report (opinion form) (Malmendier \& Tate, 2005b) and the realization form of managerial optimistic in the terms of managerial ownership (Malmendier \& Tate, 2005 and Ye \& Wulan, 2008) and managerial tenure (Frank, 1988, Weinstein, 1990, Malmendier 


\section{Jurnal Keuangan dan Perbankan | KEUANGAN}

Vol. 20, No.3, September 2016: 438- 447

\& Tate, 2005, and Frank \& Greene, 2006). But, more direct measurement of managerial optimism may be considered in the future.

According to the regression result, the Adj. R-Square shows only $34,9 \%$. It means that $65,1 \%$ variability of debt financing can be explained by another factors that are excluded in this research. So, for further research, the researchers may include the other independent variables in order to explain more about debt financing, use different sample from another industry, and use different economic condition for moderating managerial optimism on the use of debt financing.

\section{REFERENCES}

Ackert, L. \& Deaves, R. 2010. Behavioral Finance: Psychology, Decision-Making, and Markets. First Edition. South Western College.

American Psychological Association. 2013. Glossary of Psychological Terms. Retrieved 02 January 2016, from

http://www.apa.org/research/action/glossary.aspx.

Brigham, E. F. \& Daves, P. R. 2009. Intermediate Financial Management. Tenth Edition. South-Western: Cengage Learning.

DeAngelo, H., DeAngelo, L. \& Whited, T. M. 2008. Capital Structure Dynamics and Transitory Debt. Retrieved 02 February 2016, from http://ssrn.com/ abstract $=1262464$.

Frank, M. 1988. An Intertemporal Model of Industrial Exit, Quarterly Journal of Economics, 103(2): 333-44.

Frank, M. Z. \& Goyal, V. K. 2003. Capital Structure Decisions: Which Factors Are Reliably Important?. Retrieved 1 Januari 2016 from

http://citeseerx.ist.psu.edu/viewdoc/download? doi=10.1.1.203.4822Erep $=$ rep $1 \mathcal{E}$ type $=p d f$

Fraser, S. \& Greene, F. 2006. The Affect of Experience on Entrepreneurial Optimism And Uncertainty, Economica, 73(290): 169-92.

Gertler, M. \& Gilchrist, S. 1994. Monetary Policy, Business Cycle, and the Behaviour Of Small Manufacturing, Quarterly Journal of Economics, 109: 309-341.
Glaser, M., and Weber, M. 2007. Overconfidence and Trading Volume, Geneva Risk and Insurance Review, 32(1): $1-36$.

Hackbart, D. 2008. Managerial Traits and Capital Structure Decisions, Journal of Financial and Qualitative Analysis, 32(3): 269-286.

Heaton, J. B. 2002. Managerial Optimism and Corporate Finance, Financial Management Journal, 31: 33-45.

Jensen, M. C., \& Meckling, W. H. 1976. Theory of the Firm: Managerial Behavior, Agency Costs, and Ownership Structure, Journal of Financial Economics, 3(4): 305-360.

Kumar, K. B., Rajan, R. G. \& Zingales, L. 2001. What Determines Firm Size?, Retrieved 04 March 2016 from

http:/ / faculty.chicagobooth.edu/finance/papers/ size.pdf

Malmendier, U. \& Tate, G. 2005. Does Overconfidence Affect Corporate Investment? CEOOverconfidence Measures Revisited, European Financial Management Journal, 11(5): 649-659.

Malmendier, U. \& Tate, G., 2005b. Who Makes Acquisitions? CEO Overconfidence and the Market's Reaction'. Working Paper. Stanford University.

Malmendier, U. \& Tate, G. 2008. Who Makes Acquisitions? CEO Overconfidence and The Market's Reaction, Journal of Finance Economics, 89: 20-43.

March, J. \& Sharpia, Z. 1987. Managerial Perspectives on Risk and Risk Taking. Management Science, 33: 1404-1418.

Meggison, W. L. 1997. Capital Finance Theory. AddisonWesley. PP 1-506. ISBN 0673997650, 9780673997654

Miller, M. H. 1977. Debt and Taxes, Journal of Finance. 261-275.

Moeljadi, \& Supriyati, T. S. 2014. Factors Affecting Firm Value: Theoretical Study on Public Manufacturing Firms in Indonesia, South East Asia Journal of Contemporary Business, Economiics, and Law. 15(2): 6-15.

Myers, S. C. 1976. Determinants of Corporate Borrowing. Working Paper. 875-76. Sloan School of Management-Massachusetts Institute of Technology. 


\section{Managerial Optimism and Debt Financing: Case Study on Indonesia's Manufacturing Listed Firms \\ Gesti Memarista}

Park, C. \& Kim, H. 2009. The Affect of Managerial Overconfidence on Leverage, International Business and Economics Research Journal. 8(12): 115-126.

Rajan, R. G. \& Zingales, L. 1995. What Do We Know About Capital Structure? Some Evidence From International Data, The Journal of Finance, 50(5): 14211460 .

Roll, R. 1986. The Hubrys Hypothesis of Corporate Takeovers, The Journal of Business. 59(2): 197-216.

Ross, S. A., Westerfield, R., \& Jordan, B. D. 2008. Corporate Finance Fundamentals. United State: Mc Graw-Hill/ Irwin.
Valentin, C. 2015. Determinants of Corporate Financial Performance. Retrieved 9 September 2015 from

$$
\text { http://www.dafi.ase.ro/revista/6/ }
$$
Costea $\%$ 20Valentin.pdf

Weinstein, N. 1980. Unrealistic optimism about future life events, Journal of Personality and Social Psychology, 39: 806-820.

Ye, B. \& Wuhan. 2008. Managerial Overconfidence and Corporate Investment: Evidence from P. R. China, Journal of American Academy of Business. 13(1): 246252 